\title{
樹木の植栽が都市の風通しや温熱環境に及ぼす影響 Effects of Tree Planting on Ventilation and Thermal Environment in Urban Area
}

吉田伸治*

Shinji YOSHIDA

\section{1.はじめに}

みどりは人類誕生以前より地球上に存在し、人類含め 多くの生物の営みに深く関わってきた。街路樹は我々が 都市の中で「みどり」を身近に体感できる最も基本的な 要素であり、都市空間における気温低下、水蒸気の放出、 日射遮蔽、大気の浄化 (光合成)、斜面地の保護、火災時 の延焼防止、美観・景観の形成、レクレーションの場の 提供、動物への生活の場の提供等、物理的なものから心 理的なものまで多岐にわたる機能が期待されている ${ }^{11}$ 。特 に、近年深刻な都市のヒートアイランド現象の対策技術 として最も頻繁に活用される。真夏の都心部で街路樹の 樹冠が天空を覆う低温で適度な風通しのある快適な空間 は「クールスポット」と呼ばれ、その必要性が広く認め られている。

本稿では都市空間に不可欠な「みどり」と風通しに関 して、計算流体力学 CFDによる検討例を交えながら説明 する。本稿前半では、植栽の屋外温熱環境に与える複合 的影響の中での風通しの変化がもたらす影響の大きさを 説明し、後半では、季節に応じた防風・利風を可能とす る樹木帯形状に関するケーススタディの内容を紹介する。

\section{2. 植栽が屋外空間の温熱環境に与える複合的影響}

都市のヒートアイランド現象の対策技術を都市全体の

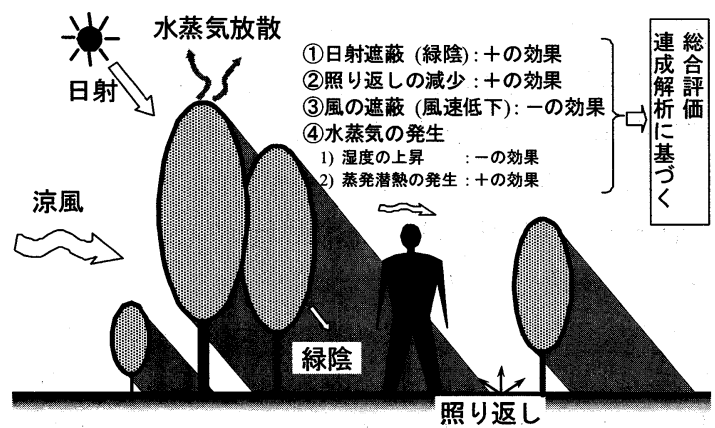

図1 植裁が夏季の温熱環境に与える複合的影響 ${ }^{2)}$
マクロな視点で捉える場合、街路樹等の地表の「みどり」 は設置された空間及びその周辺の気温を低下させるため、 その現象の緩和に大きく貢献する点に疑いの余地は無い。 しかし、近年、その問題一の関心の高まりは、建物周辺 や街路空間の様なミクロな空間スケールにおける夏季の 温熱環境が耐光難いものとなり、その緩和が求められて いるためと考えられる。この様なミクロな空間スケール の視点から街路樹の建物周辺・街路空間の温熱快適性に 与える影響を考える場合、その評価はやや複雑なものと なる。なぜなら、図 1 に示すように、街路樹の植栽は、 日射遮蔽、照り返しの減少、気温低下という点では夏季 の熱環境緩和に貢献する反面、風通しの悪化や湿気の増 加といった悪化の要因も併せ持つためである ${ }^{2) ~ 3) 。 そ の ~}$ ため、対策技術として街路樹の設置が夏季の屋外温熱環 境をどの程度緩和可能か定量的に評価するのは難しく、 CFD 連成数值解析に基づく総合的な屋外温熱環境評価技 術の活用が最も有効と考えられる。

3. CFD 連成数值解析に基づく屋外温熱環境評価手法

3. 1 評価手法の流れ

屋外温熱環境予測手法の流れを図 2 に示す ${ }^{2)}$ 。先ず、左端 のプロセスにおいて各種入力条件（Input data 1３）より境 界条件を設定する。次に中央のプロセスの前段階において 放射計算を実行する。放射計算より得られた地表面や壁体 表面の温度分布等を境界条件として与え、対流·湿気輸送連 成 CFD 解析を行う。その結果、新たな風速、温度、湿度の 分布が与えられ、これにより地表面、壁体表面からの顕熱 輸送量や潜熱輸送量が変化し、地表面や壁体表面の熱収支 も変るので、この条件下で再び放射計算を行う。これら一 連の操作（中央のプロセス）の反復により CFDに基づく対 流・放射・湿気輸送連成シミュレーションが完成する。解 析の結果、風速、温度、湿度、平均放射温度MRT (Mean Radiant Temperature) の空間分布が得られる。さらに人体の着衣量、

* 福井大学大学院工学研究科 准教授

Associate Professor, Faculty of Engineering, University of Fukui 


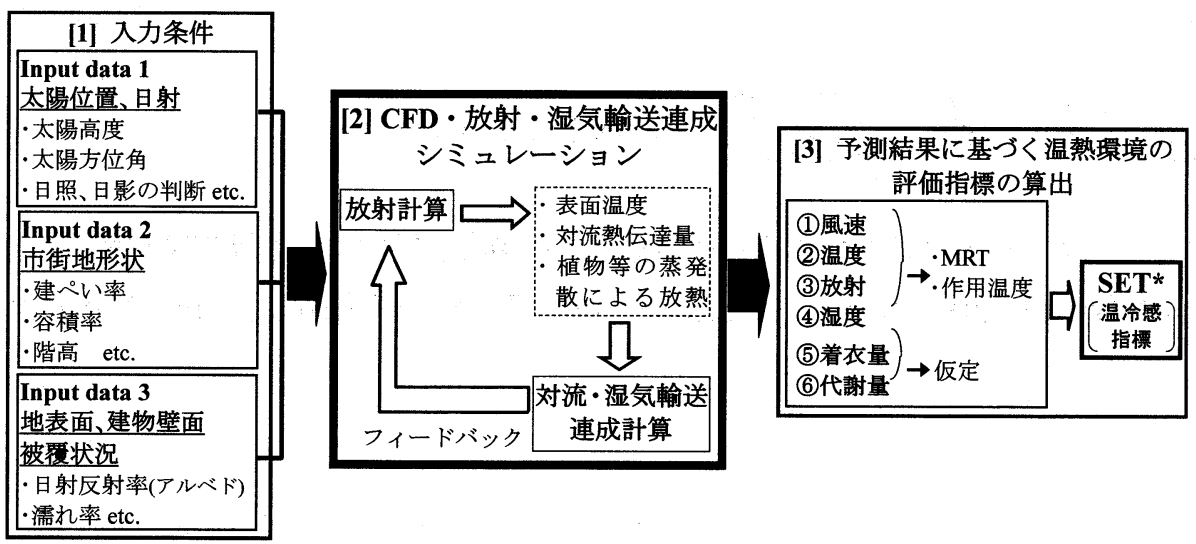

図 2 屋外温熱環境における SET*予測のための連成解析のフローチャート

代謝量を仮定することにより温熱快適性の評価指標である 新標淮有効温度 SET ${ }^{* 4)}$ の空間分布が計算される。

3. 2 植栽による環境形成の物理メカニズムを考慮し た樹木モデルの組み込み

樹木が屋外の温熱空気環境形成に及ぼす影響には種々 存在するが、主なものとして図3に示す3つが挙げられる。

(1) 樹木の流体力学的影響（風速低下と乱れの増加）

(2) 樹木による日射等の放射减衰の効果

(3) 樹木からの蒸散による潜熱放散を含む熱収支への 影響

このように、環境に対し複雑な影響を及ぼす樹木のモ デル化については、単純なものから極めて複雑なものま で様々なものが提案されている ${ }^{5)}$ 。筆者らは、上述の屋 外温熱環境評価手法への組み込み時の実用性に配慮した 上で、それら3つの影響を考慮した樹木モデルを開発した 3)。次章以降の解析ではこの樹木モデルを用いている。

4. 植栽の規模・種類の違いが屋外空間の風通し・温熱 環境に及ぼす影響の数值解析

4. 1 解析対象・解析ケース

緑化の効果を検討するのに適切な街区モデルとして図 4に示すものを設定した。ここでは立方体建物モデル（1 辺 $30 \mathrm{~m} ）$ で構成される均等街区を想定している。東京の7 月下旬午後 3 時の気象条件を選び、草地や樹木が街区の温 熱環境に及ぼす影響を検討している。

解析ケースを表1ならびに図5に示す。case 1-1（地表面 の草地率を $10 \%$ とした場合（樹木なし）、 case 1-2（地表 面を全面草地（草地率100\%）とした場合（樹木なし）、 case 1-3（地表面全面草地十地上 $2 \mathrm{~m}$ より上部に直径 $4 \mathrm{~m}$ の 樹冠をもつ樹木(樹種ニセアカシア、葉面積密度 $1.0 \mathrm{~m}^{2} / \mathrm{m}^{3}$ ) を5m間隔で均等に配置した場合)、の3ケースの解析が行

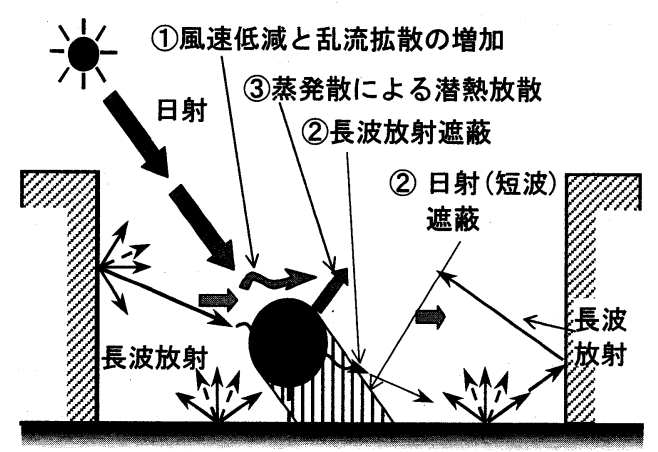

図 3 環境緩和効果を組み込んだ樹木モデルの概念図

われた ${ }^{3)}$ 。なお、ここでは緑化や植栽の影響を比較するた めやや極端なモデル化を行っている。

地表面の草地は芝生等の丈の低い緑地を想定し、その

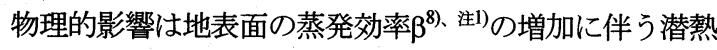
放散の増加と、それに伴う顕熱量の減少により評価する。

また、建物間の相互反射の影響を考慮するため東西、

南北に各々3個ずつ、合計9個の建物が並んだ空間を対象 に放射計算を行い、解析領域中心の建物並びにその近傍 の地表面、建物壁面温度をCFD計算の境界条件に使用し た。また、対流計算における風速、温度、絶対湿度の水 平方向の境界条件は周期境界条件を用いた。即ち、地表 面・建物壁面で発生した熱や水蒸気は、全て上空境界よ り排出される。地表面、建物壁面における速度の境界条件 には便宜的に一般化対数則2), 9)を使用し、熱の境界条件と しては対流熱伝達率型の壁関数を用いた。その他、計算 条件・手法の詳細は文献3を参照されたい。

\section{2 風速ベクトル分布}

風速ベクトルの水平分布 (地上 $1.5 \mathrm{~m}$ ) を図 6 に示す。 いずれのケースも建物間に循環流が生じており、これが 後に示す気温分布に大きく影響する。 case 1-3 (全面草地、 全面樹木）は樹木の風速低减効果により、樹木の存在し 


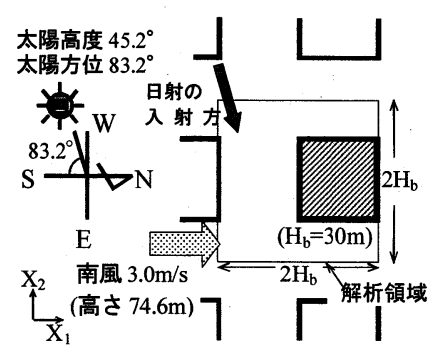

(1)平面図

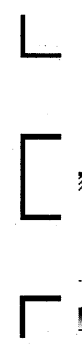

図

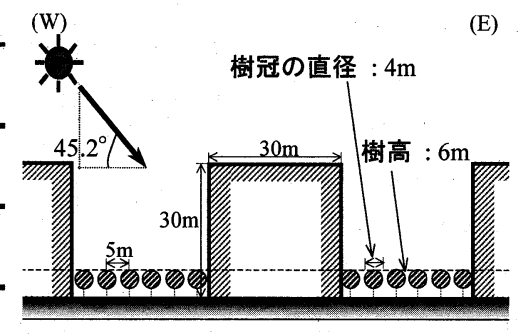

(2)断面図 (case1-3)

)

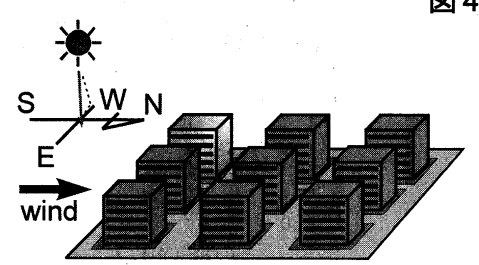

(1) case1-1（草地率 $10 \%$ 、樹木なし）

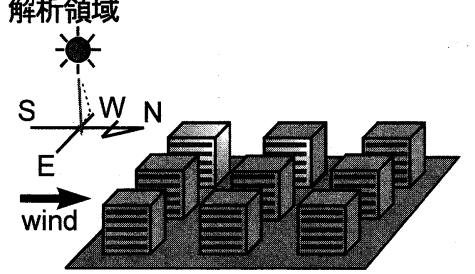

(2) case1-2 (全面草地、樹木なし)

\begin{tabular}{|c|c|c|}
\hline case & $\begin{array}{c}\text { 草地率 } \\
{[\%]}\end{array}$ & $\begin{array}{c}\text { 樹木の } \\
\text { 有無 }\end{array}$ \\
\hline casel-1 & 10 & 無し \\
\cline { 1 - 1 } casel-2 & \multirow{2}{*}{100} & $\begin{array}{c}\text { 樹高 } 6.0[\mathrm{~m}] \\
\text { の樹木を } \\
\text { 均等配置 }\end{array}$ \\
\hline
\end{tabular}

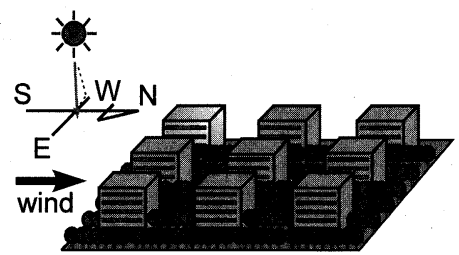

(3) case1-3（全面草地、全面樹木）

ない case 1-1（草地率 10\%、樹木なし)、case 1-2（全面草 地、樹木なし）に比べ、全般に風速が小さく、循環流域 内で約 $0.25 \mathrm{~m} / \mathrm{s} \sim 0.5 \mathrm{~m} / \mathrm{s}$ の值となる。この風速の低下は後 述する新標準有效温度 SET*を上昇させる方向に働く。

4. 3 地表面温度分布

各ケースの地表面温度分布の比較を図 7 に示す。case 1-2 は case 1-1に比べ、草地の増加に伴う地表面加らの潜 熱発生の増加により、日照部で約 $14^{\circ} \mathrm{C}$ 、日影部で約 $6^{\circ} \mathrm{C}$ 地表面温度が低下する。case 1-3 では、樹冠の日射減衰効 果により、case 1-2 に比べさらに日照部で約 $12^{\circ} \mathrm{C}$ 、日影部 で約 $2^{\circ} \mathrm{C}$ 地表面温度が低下寸る。 case 1-3 の場合、草地か らの蒸発散による潜熱放散に加え、樹冠の日射減衰効果 により地表面での日射による熱取得量が減り、地表面温 度は全体的に $26^{\circ} \mathrm{C}$ 程度の值となり、気温よりも低い值を 示す。樹木のモデル化のプロセスにおいていくつかの単 純化があり予測精度に改善の余地があるにしても、ここ に示すように樹木の温熱環境に対する影響の大きいこと は明らかであると言える。

\section{4 気温分布}

気温の水平分布 (地上 $1.5 \mathrm{~m}$ ) を図8に示す。case 1-2 は case 1-1 に比へ、循環流域内で約 $0.5 \sim 1.5^{\circ} \mathrm{C}$ 気温が低く、草地か らの蒸発散による気温低減効果が認められる。一方、case 1-3 は case 1-2 よりもさらに約 $2.0 \sim 5.5^{\circ} \mathrm{C}$ 気温が低下寸る。 3. 5 緑化の面積と種類の違いによる SET*の増減

新標準有効温度SET*の水平分布（地上 $1.5 \mathrm{~m} ）$ を図9に 示す注2)。case 1-1 と case 1-2では日照部と日影部でSET*の值 に顕著な差が生じる。case 1-1、case1-2では、共に日照部 と日影部のSET ${ }^{*}$ 差の最大が $14^{\circ} \mathrm{C}$ となる。一方、case 1-3 では樹冠の日射遮蔽効果により、SET゙は比較的均一とな

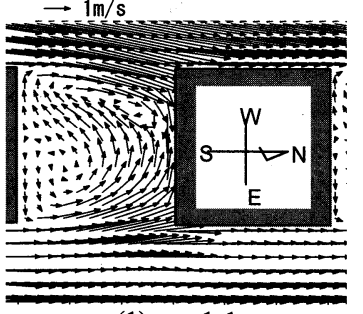

(1) case1-1

（草地率 10\%、樹木なし）

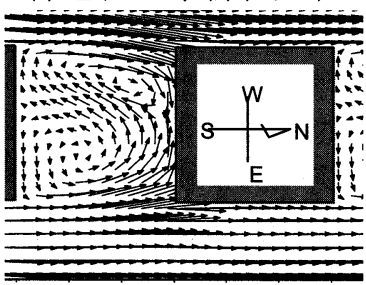

(2) casel-2

(全面草地、樹木なし)

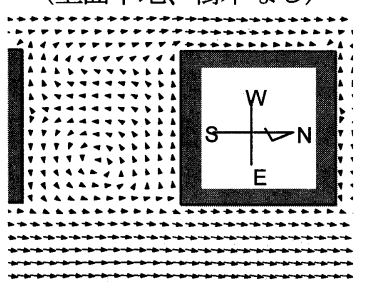

(3) casel-3

(全面草地、全面樹木)

図 6 風速ベクトルの水平分布

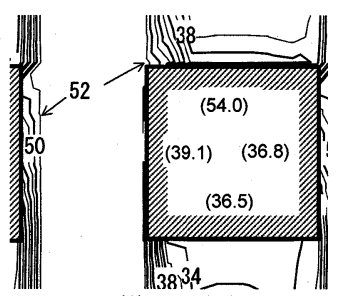

(1) case1-1

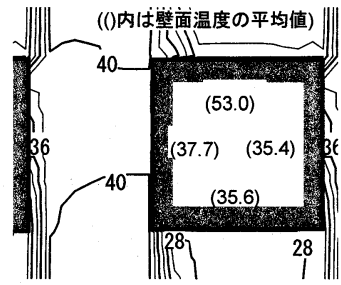

(2) case1-2

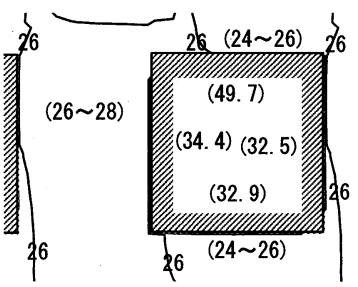

(3) case1-3 (高さ $1.5 \mathrm{~m})$

り、 $34^{\circ} \mathrm{C} \sim 38^{\circ} \mathrm{C}$ 程度の值を示す。

また、図10は緑化の面積、種類の違いによるSET"の増 减を調べたものである。図10(1)は、case 1-2のSET゙ と case 1-1のSET の差である。この図から、case1-1からcase1-2へ の草地面積の増加に伴うSET*の増減 (case 1-2-case 1-1) 
が分かる。図中の灰色の部分がcase 1-2においてcase 1-1に 比べてSET゙が減少する領域であり、白色の部分は逆に增 加する領域である。草地の増加に伴い、case 1-2のSET*は case1-1に比べ多くの領域で最大約 ${ }^{\circ} \mathrm{C}$ 低下し、温熱快適性 は向上する。次に図10 (2) にcase 1-3 とcase 1-2 のSET*の 差 (case 1-3-case 1-2) を示す。この事例では樹木の配置 に伴いSET*が上昇する領域（白色の領域）の方がSET が低下寸る領域 (扊色の領域) よりやや大きくなってお り、樹木の配置により必ずしも夏季の快適性が向上する とは限らない結果になっている。

以上の解析結果をまとめると、本章の解析では草地面 積の増加は温熱快適性を向上させ、樹木の配置は逆に快 適性を悪化させる結果となった。この様な結果となった 要因は、case1-3において地表全面に樹木を配置したこと により生じる過度の風速低下と湿度上昇が原因である。 地表全面に樹木を設置するという、やや過剩なケースで あることに留意する必要はあるが、この結果は植栽によ る温熱環境緩和効果を期待する場合、樹木の適切な密度 と配置に配慮する必要があることを示唆している。

次章では、この風通しの屋外温熱快適性に与える影響 の大きさを踏まえ、季節に応じた防風・利風を可能とす る樹木帯の配置を検討した解析例を紹介する。

5. 河川風の防風・利風を図るための樹木帯・フェンス の配置の検討

エコロジカルな都市づくりにおいて、河川沿岸や臨海 部等の親水空間の利用が注目されている。河川や海洋上 の新鮮冷気を街区に誘引することは夏季の屋外温熱環境 の緩和に非常に有効である。また冬季には、冷風の流入 を如何に抑制するかが屋外環境計画上重要となる。成田 ${ }^{10)}$ は、風洞実験により河川周辺の建物配列が街区の微気 象に及ぼす影響を検討している。著者らも CFD 解析によ り建物配置の変更の有無が河川からの冷風の取り入れに 及ぼす影響を検討している ${ }^{11)}$ 。本章では、河川沿岸にお いて夏季は河川風を誘引し、冬季はそれを防止する様な 樹木帯、フェンスの配置についての検討例を紹介する。

\section{1 解析概要}

図 11 の河川とこれに沿った陸を解析対象とする。河川 水面上の風向は季節によって異なる場合が多く、例えば 関東地方の日中においては、夏は海から内陸へと上流に 遡上し、冬は内陸から海へと下流方向に吹くことが多い。 これを踏まえ、図 11 左側を海側、右側を内陸側と考え、 夏は図中左から冬は逆に図中右から風が流入すると想定 する。この様な風向変化に応じて、夏の川風を陸地へ誘

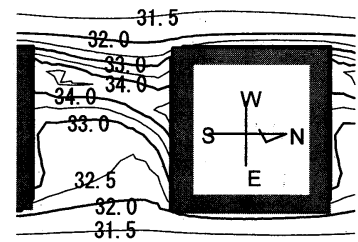

(1) case1-1

(草地率 $10 \%$ 、樹木なし)

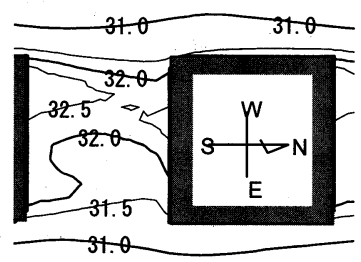

(2) case1-2

(全面草地、樹木なし)

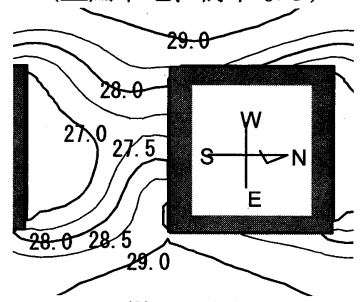

(3) case1-3

(全面草地、全面樹木)

図 8 気温の水平分布

(高さ $1.5 \mathrm{~m}$ )

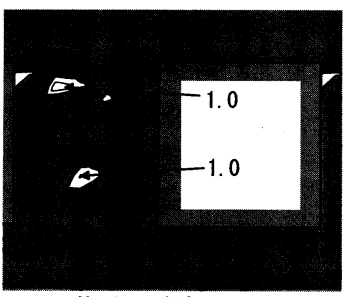
の増減 (case1-2-case1-1)
(1) 草地の増加による SET*

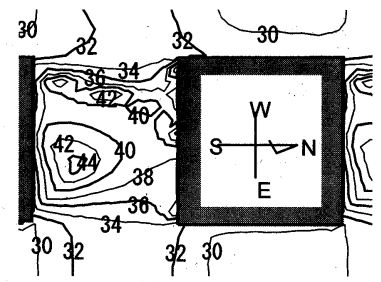

(1) case1-1

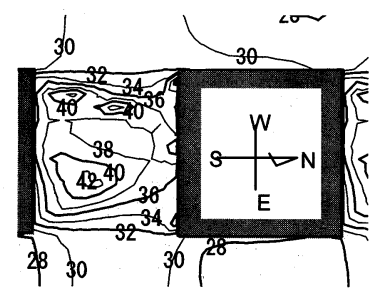

(2) case1-2

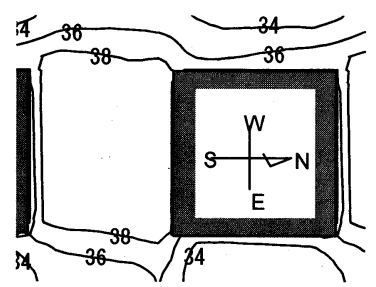

(3) case 1-3

図 $9 \mathrm{SET}{ }^{\star}$ の水平分布 (高さ $1.5 \mathrm{~m}$ )

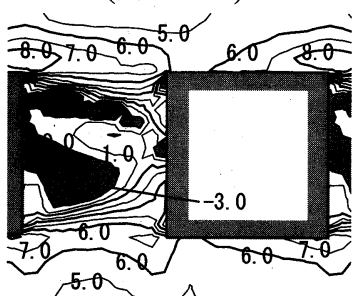

(2) 樹木の植栽による SET* の増減(case1-3-case1-2)
図 10 緑地の種類と面積の違いによる SET*の増減

(高さ $1.5 \mathrm{~m}$, 単位 : ${ }^{\circ} \mathrm{C}$ )

( . 図中の灰色の領域は SET*の変化が負の值を示し,温熱快適 性が向上したことを示す。

引し、且つ冬の川風の侵入を抑制するため、樹木帯をル ーバー状に配置する。

樹木帯の構成樹種は、図 12 に示すシラカシ (高木)、 ツツジ（低木）を想定する。ただし計算では幹は考慮さ れない。これらの樹木が流れ場に及ぼす影響を表 2 のパ ラメータによりモデル化する。

解析ケースを表 3 に示す。また、各ケースの樹木並び にフェンスの配置を図 13 に示す。case2-0 は植栽を全く配 置しないケースである。case2-1 は高木のシラカシのみに よる樹木帯を配置したケースである（図 13(1)）。case2-2 
では、歩行者空間の冬季の防風に配虑し、シラカシに加 えてツツジを併用した樹木带を配置する（図 13(2)）。 case2-3 では河川と陸地の境界付近の風の流れを効果的に 制御するため、フェンスを併用する(図 13(3))。これら の解析により、樹木帯の構成の違いが流れ場、河川付近 の新鮮空気の到達状況に及ぼす影響を検討する。

また本解析では河川近傍の空気は新鮮で泠涼であると 想定する。そのため、特に夏季においてはこの冷気を陸 地に誘引し、冬は逆にその流入を抑制したい。そこで、 河川上に位置する流入境界 (図 11 参照) からトレーサー ガスを放出した灌度解析を行い、その到達状況を比較す る。その他の計算条件については文献 12 を参照されたい。 5.2 風速変化率の水平分布

まず、全く植栽の無い case2-0 のスカラー風速に対する case2-1 case2-3 の值の比を算出した風速変化率により結 果を分析する。図 14 が夏季における風速変化率の水平分 布(高さ $1.5 \mathrm{~m}$ )を示しており、図 15 が冬季の結果である。 図中の灰色の領域は風速変化率が 0.2 以下の領域であり、 植栽による風速低下の大きな領域を表す。case2-1 におい ては、夏は河川から離れた領域に、冬は逆に河川近傍に 風速変化率 0.2 以下の領域が形成される。case2-2 では低 木の配置に伴い、case2-1 に比べ風速変化率 0.2 以下の領 域が大幅に増加する。フェンスを併用した檄木帯を用い た case2-3 では、夏の方が冬に比べて風速变化率が 0.2 以 下の領域が若干増えるものの、場所によっては夏の方が
風速変化率の大きな値を示寸領域も見られる。

5. 3 河川上の新鮮空気の樹木帯内部への到達状況 図16に夏季における河川付近加らの流入空気の数度分 布と風速ベクトル分布を示す。図17が冬季の結果である。 ここでの濃度の值は河川上の流入境界における值を 1 と して基準化したものである。case2-1、case2-2 では河川上 においては夏の方が冬より高い值を示すものの陸上では 夏冬ともにほぼ $0 \sim 0.1$ 程度の值を示し、河川上の空気が 殆ど到達しない。一方、case2-3 ではフェンスの配置に伴 い夏は河川から樹木帯内部人、冬は樹木帯内部から河 川に向かう強い流れが生じている。その結果、夏季の解 析において風上から 2 列目と 3 列目の樹木帯の間でトレ 一サーガス濃度が 0.1 0.2 程度の值を示し、逆に冬季は 殆ど0の值となり、夏の利風と冬の防風が害現する。

\section{6. まとめ}

本稿では、CFD 解析の例を踏まえながら、樹木の植栽 が都市の風通しや温熱墂境に及ぼす影輴について説明し た。街路樹にはヒートアイランド緩和、夏季屋外温熱環 境の緩和に対する貢献が期待されている反面、対策技術 として建筑・都市空間の設計に効果的に組み込むために は解決す心゙き多くの課題がある。今後は、配置間隔、樹 高、救種、管理 (剪定) 方法の違いに対する評価、四季 を通じた評価の視点が必要であり、実測、数値シミュレ ーションによる更なる検証等、研究の進展が期待される。

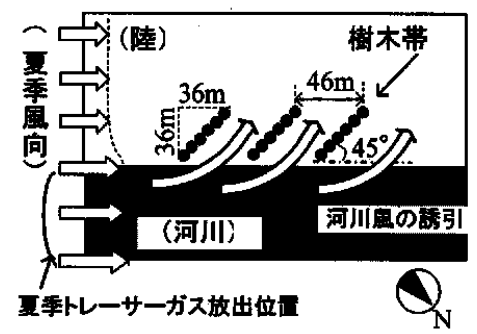

(1) 夏季

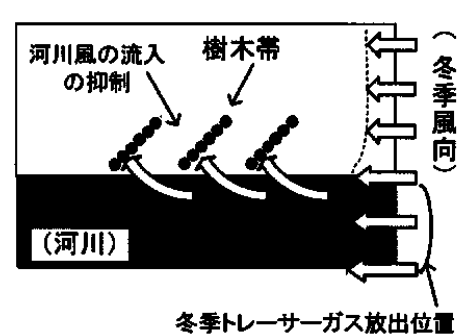

(2) 冬季

图 11 解析対象

表 2 樹木のパラメータ

\begin{tabular}{|c|c|c|}
\hline & 莱面椋密度 $\left[\mathrm{m}^{2} / \mathrm{m}^{3}\right]$ & 抗力係数 [-] \\
\hline 恸シ & 4.00 & 0.4 \\
\hline 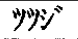 & 8.80 & 0.2 \\
\hline
\end{tabular}

表 3 解析ケース

\begin{tabular}{|l|l|}
\hline case 0 & 樹木带なしの場合 \\
\hline case2-1 & $\begin{array}{l}\text { 高木のみにより構成される㨽 } \\
\text { 木带を配置した場合 }\end{array}$ \\
\hline case2-2 & $\begin{array}{l}\text { 高木、低木よりなる樹木帯を配 } \\
\text { 直した場合 }\end{array}$ \\
\hline case2-3 & $\begin{array}{l}\text { case2-2 の樹木帯の一部の樹木 } \\
\text { をフェンスに変更した場合 }\end{array}$ \\
\hline
\end{tabular}

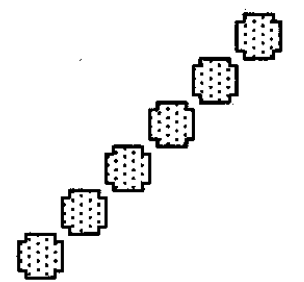

(1) 高木

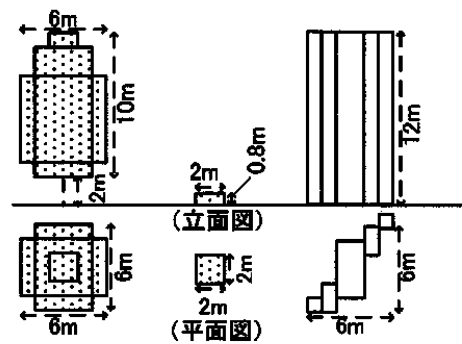

$\begin{array}{lll}\text { （1）高木 } & \text { (2) 低木 } & \text { (3) フェンス }\end{array}$

图 12 本研究て使用する榯木モデル の形状

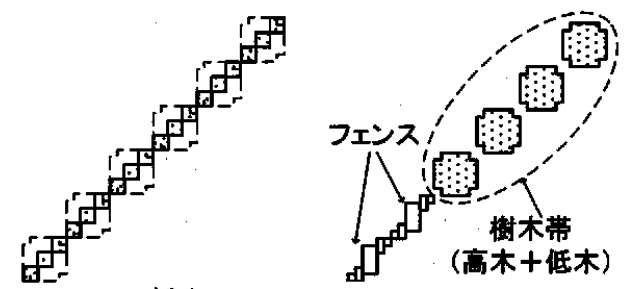

(3) フェンス 


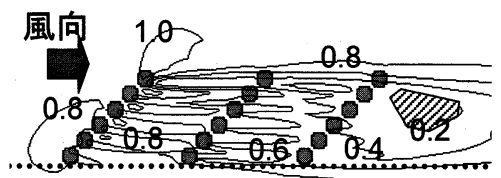

河川

(1) case2-1（高木）

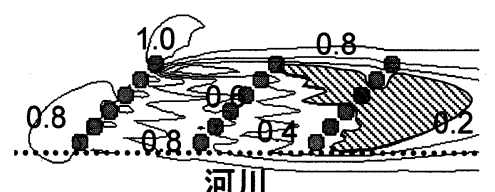

(2) case2-2（高木+低木）

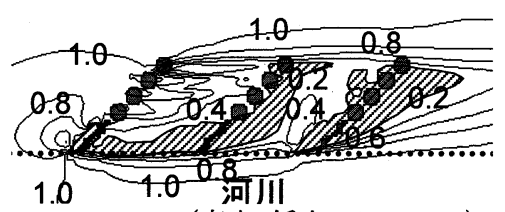

(3) case2-3（高木+低木+フェンス）

図 14 夏季における風速分布 (地上 $1.5 \mathrm{~m}$ 、風速変化率として示す)

[風速変化率＝（case2-1、2、3 のスカラー風速）/（case0 のスカラー風速）、斜線部 : 風速変化率が 0.2 以下の領域]

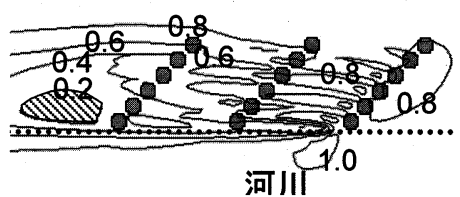

(1) case2-1 (高木)

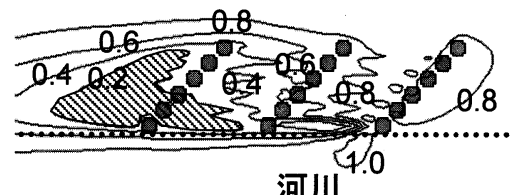

(2) case2-2（高木十低木）

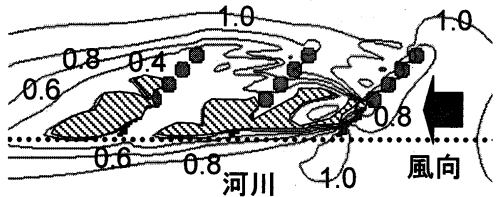

(3) case2-3（高木+低木十フェンス）

図 15 冬季における風速分布 (地上 $1.5 \mathrm{~m}$ 、風速変化率として示す)

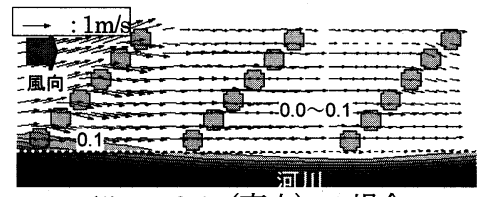

(1) case2-1（高木）の場合

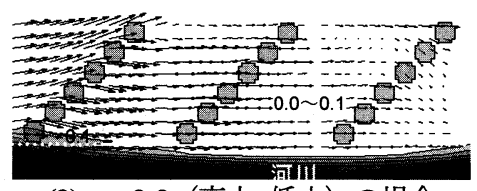

(2) case2-2（高木+低木）の場合

図 16 川の新鮮空気の濃度分布と風速ベクトル分布

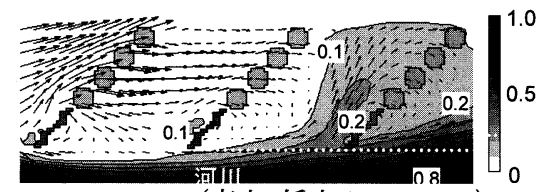

(3) case2-3（高木+低木+フェンス）

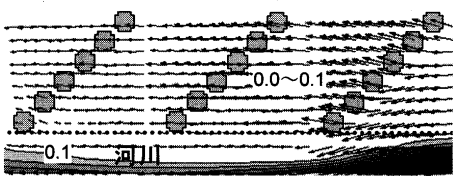

(1) case2-1（高木）の場合

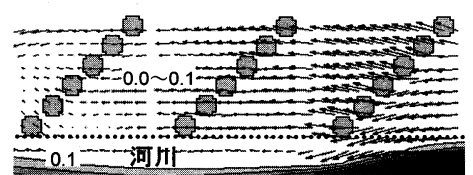

(2) case2-2（高木+低木）の場合

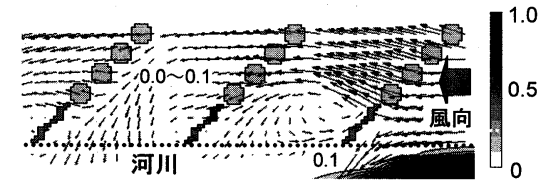

(3) case2-3（高木+低木+フェンス）

図 17 川の新鮮空気の濃度分布と風速ベクトル分布（冬季、高さ $1.5 \mathrm{~m}$ )

注1) 地表面の蒸発効率々とは、地表面の濡れ具合を示しており、 地表面が十分湿っている場合は 1 に近い值を、完全に乾燥 している場合は 0 の值を示す。

注2) SET*は人体を暑熱罿境に曝露して 1 時間後の皮膚温度,濡 れ率を用いて算出された。ここで、歩行者の着衣量を $0.5 \mathrm{clo}$ (半袖シャツとズボンの着衣状態に対忍)、代謝量を $1.5 \mathrm{Met}$ (ゆっくりした歩行と立位静止時の中間)と与え、人体の平均 対流熱伝達率は Mitchel の式を用いて算出された。 参考文献

1) 森山正和編，ヒートアイランド対策の技術，学芸社出版， 2004.8

2) 村上周三, CFD による建築·都市の環境設計工学, 東京大学出 版会, 2000.9

3) 吉田伸治, ほか, 樹木モデルを組み込んだ対流・放射·湿気輸 送連成解析による樹木の屋外温熱環境緩和効果の検討, 日本 建築学会計画系論文集, 第 536 号, pp.87-94, 2000. 10

4) A. P. Gagge et al., A Standard Predictive index of human response to the thermal environment, AHSRAE Transactions, 92(1), 709-731, 1986
5) 平岡久司, 樹木の熱・水分·二酸化炭素収支のモデル化に関す る考察, 日本建築学会計画系論文集, 546 号, pp.53-60, 2001.8

6) 大橋征幹, 単独樹木周辺の気流解析に関寸る研究, 日本建築 学会環境系論文集, 578 号,pp.91-96,2004.4

7) 花平愛, ほか, 温熱環境改善のための樹木の蒸散作用モデル に関する基礎的研究，日本建築学会環境系論文集, 598 号, pp.71-78, 2005.12

8) 近藤純正, 水環境の気象学, 朝倉書店, 1994

9) B. E. Launder et al., The Numerical Computation of Turbulent Flows, Computer Methods in Applied Mechanics and Engineering 3, 269-289, 1974

10)成田, 都市内河川の微気象的影響範囲に及ぼす周辺建物配列 の影響に関する風洞実験，建築学会計画系論文報告集,第 442 号, 27-35, 1992.12

11) 大黒雅之, ほか, CFD を利用した屋外温熱空気環境設計手法 に関する研究一川風の温熱空気環境改善効果の解析一, 日本 建築学会技術報告集, 16 号, 185-190, 2002.12

12) 吉田伸治, ほか, CFD 解析による河川風の防風・利風を図る ための樹木帯・フェンスの配置に関する研究，日本建築学会 大会学術講演梗概集, D1, 605-606, 2003 